\title{
HIDUP SETELAH MENIKAH, MENGURAI EMOSI POSITIF DAN RESILIENSI PADA WANITA TANPA PASANGAN
}

\author{
Yulia Sholichatun \\ Dosen Fakultas Psikologi Universitas Islam Negeri Malang
}

\begin{abstract}
Abstrak
Divorce and the death of spouse can be a painful and sometimes delibitating experiences.However, bereaved individuals differ markedly in how much and how long they grieve.positives emotions may be most benefecial, however when they are at the time of stress. Positive emotions contribute to psychological well-being via more effective coping. The experience of positive emotiopns functions to assist reilient individuals in their ability to recover effectively from bereavement.
\end{abstract}

\section{A. Pendahuluan}

Terdapat banyak pendekatan untuk mengkonsepkan dan mengoperasionalkan faktorfaktor yang mempengaruhi kemampuan manusia dalam melakukan penyesuaian. Konstruk yang terkait dengan kemampuan manusia dalam melakukan penyesuaian antara lain adalah resilience. Penggunaan istilah resilien telah mengalami peningkatan dalam beberapa dekade terakhir. Resilien merupakan sebuah atribut penting yang menjadi perpaduan antara kemampuankemampuan dan karakteristik-karakteristik yang berinteraksi secara dinamis untuk memberikan ketegaran individu dalam menghadapi segala tantangan dalam kehidupan secara sukses. ${ }^{1}$ Resilien telah banyak dikaji terutama dalamhubungannya dengan transisi-transisi dari stres-stres berat termasuk stres yang dimunculkan oleh transisi developmental seperti awal masuk sekolah,pengasuhan anak, dan lain-lain. Transisi juga muncul dari kejadian-kejadian eksternal yang tidak diharapakan seperti bencana, PHK atau krisis ekonomi nasional yang mempengaruhi munculnya problem di tingkat individu dan keluarga. Bentuk-bentuk situasi stress semacam ini

\footnotetext{
1 Tusaie, K \& Dyer, J. 2004. Resilience: a historical review of the construct. Holistic Nursing Practice. January/February, 1-7.
} 
dan bentuk-bentuk stress lain telah menempatkan individu dalam kondisi beresiko yang dapat memunculkan simton-simton fisik maupun psikologis.

Perpisahan merupakan salah satu realitas kehidupan manusia yang sering tak terelakkan. Kehilangan pasangan dapat menjadi salah satu fenomena hidup yang dapat menimpa seorang wanita. Pada sebagian wanita, fenomena ini menjadi suatu fenomena yang traumatik, dan memberikan efek melemahkan diri dan kehidupan wanita tersebut setelah menjalani kehidupan tanpa pasangan. Namun bagi sebagian wanita yang lain, kehidupan sepeninggal pasangan dapat menjadi suatu media diri untuk berkembang menuju pada kematangan, hampir tanpa diiringi oleh munculnya problem psikologis jangka panjang yang dapat menghilangkan kesejahteraan hidup wanita tersebut.

Dalam literatur, istilah widow dibedakan dengan divorcee sekalipun memiliki kesamaan sebagai wanita yang kehilangan pasangan. Kata widow digunakan pada wanita yang kehilangan suami karena meninggal dunia, sedangkan divorcee lebih pada wanita yang mengalami pereceraian, yang dibuktikan oleh adanya surat resmi perceraian. ${ }^{2}$

Tulisan ini akan memaparkan bagaimana dinamika emosi wanita yang kehilangan pasangan, bagaimana dampaknyapada munculnya proble-problem psikologis, dan bagaimana pada sisi yang sebaliknya, relisiensi psikologis dapat diperoleh oleh wanita yang kehilangan pasangan.

\section{B. Dinamika Psikologis}

Hasil-hasil penelitian psikologi mengenai efek kehilangan pasangan terhadap para wanita yang menghadapinya cukup beragam. Secara umum, baik wanita yang kehilangan pasangan hidupkarena suaminya meninggal dunia atau karena perceraian, mereka dihadapkan pada realitas yang hampir sama. Untuk memahami banyaknya tantangan wanita yang menghadapi kondisi kehilangan pasangan, maka menjadi sebuah kebutuhan untuk memahami apa yang benar-benar hilang ketika perkawinan berakhir. Bagi sebagian wanita, akhir perkawinan berarti hilangnya pasangan hidup, teman hidup dan orang yang bisa dipercaya. Bagi wanita lain, berakhirnya

\footnotetext{
${ }^{2}$ Utz, R.L. 2005. The single older woman: life after marriage. Book Reviews. The Gerontologist: June, 45, 3.
} 
perkawinan mencerminkan rasa kehilangan terhadap pencari nafkah untuk kehidupan rumah tangga atau kehilangan orang yang akan memperbaiki kerusakan-kerusakan peralatan rumah. Dengan kata lain, menurut ${ }^{3}$ sifat kehilangan yang dirasakan oleh seorang wanita terhadap pasangannya sangat berhubungan dengan sejarah hubungan wanita tersebut dengan pasangannya. Makin panjang usia perkawinan, hubungan tersebut memiliki makin banyak sejarah yang mungkin berhubungan dengan banyak aspek dibandingkan dengan mereka yang usia perkawinannya masih pendek.

Ketika dua orang memasuki perkawinan, mereka telah mengikat komitmenuntuk saling mencintai dan menghormati satu sama lain. Mereka juga mulai berfungsi sebgai sebuah unit atau sebuah tim. Dalam perkawinan, pasangan suami isteri dapat lebih efisien dan produktif dibandingkan apabila mereka menjalani kehidupan sendiri-sendiri. Karena itu, ketika perkawinan sampai pada titik akhir baik karena kematian pasangan atau karena perceraian, maka tim itu mengalami kehancuran. Salah satu pasangan yang bertahan menjadi harus bertanggungjawab dengan seluruh tugas harian dalam kehidupan termasuk tugas-tugas yang awalnya dilakukan secara bersamaan dengan pasangannya. Termasuk dalam hal ini seorang wanita yang kehilangan pasangan juga harus tetap menjalankan aktivitas hariannya, misalnya untuk mengurus rumah tangga, sementara dalam waktu yang bersamaan ia merasakan kesedihan karena kehilangan hubungan dengan orang terdekat. Tujuan wanita yang kehilangan pasangan ini bukan lagi mengembalikan kehidupan yang dijalaninya sebelumnya, tetapi membangun kembali kehidupannya sehingga merefleksikan realitas kehidupannya yang baru sebagai seorang wanita tanpa pasangan. ${ }^{4}$

Sebuah teori populer yang disebut sebagai the Dual Process of Coping ${ }^{5}$ menjelaskan bahwa wanita yang mengalami kehilangan terombang-ambing diantara pengatasan maslah yang berorientasi pada rasa kehilangannya dan pengatasan masalah yang berorientasi terhadap pemulihan. Pengatasan maslah yang berorientasi pada kehilangan membawa wanita pada rasa kehilangan yang bersifat sangat emosional terhadap pasangan hidup, sedangkan pengatasan maslah yang berorientasi pemulihan membawa wanita pada keadaan untuk membangun kembali

\footnotetext{
${ }^{3}$ Ibid.

4 Ibid.

5 Stroebe \& Schut dalam Utz, R.L. 2005. The single older woman: life after marriage. Book Reviews. The Gerontologist: June, 45, 3.
} 
aktivitas harian dan hubungan sosial yang mungkin terganggu karena hilangnya pasangan. Oleh karena itu, kehilangan pasangan merupakan proses multidimensi yang mana wanita yang mengalami kehilangan harus menghadapi kehilangan secara sosial, psikologis, finansial dan instrumental yang berhubungan dengan perkawinan yang berakhir. ${ }^{6}$

Hasil-hasil penelitian dalam psikologi memberikan pembedaan antara kehilangan yang disebabkan oleh kematian pasangan dan kehilangan yang disebabkan oleh perceraian. Dibandingkan perceraian, kematian pasangan dipandang sebagai kejadian hidup yang paling besar potensinya untuk mendatangkan tekanan. ${ }^{7}$ Meskipun mayoritas wanita yang menjadi janda karena kematian suami dapat beradaptasi dengan kehilanghan seiring dengan berjalannya waktu, namun diperkirakan antara $20-40 \%$ diantara para wanita yang kehilangan tersebut tidak pernah pulih secara penuh. ${ }^{8}$

Akibat dari kehilangan pasangan sering dihubungkan dengan meningkatnya resiko munculnya simtom-simtom depresi ${ }^{9}$ serta simtom yang berhubungan dengan kecemasan. ${ }^{10}$ Simtom depresi dan kecemasan ini pada waktunya akan cenderung muncul secara bersamaan yang menunjukkan variasi simtom intra individual selama beberapa bulan segera setelah kehilangan pasangan. ${ }^{11}$ Bonanno \& Kaltman $^{12}$ menyatakan bahwa perbedaan wanita dalammenghadapi kehilangan berhubungan dengan sebesar dan sepanjang apa mereka merasa kehilangan. Perbandingan terhadap hasil-hasil penelitian mengenai kehilangan telah mengungkapkan adanya tiga pola dasar, yaitu: a) adanya gangguan fungsi psikologis selama waktu tertentu misalnya yang ditandai oleh depresi, disorganisasi kognitif dan problem kesehatan selama beberapa bulan hingga 1 atau 2 tahun, b) gangguan kronik dalam fungsi psikologis yang berlanjut hingga beberapa tahun atau lebih, c) ketiadaan depresi dan gangguan fungsi psikologis

\footnotetext{
${ }^{6}$ Utz, R.L. 2005. The single older woman

7 Miller\& Rahe, dalam O'Rourke, 2004; Gallagher, Breckenridge, Thompson \& Peterson, 1983 dalam Ong, Bergeman, \& Bisconti, 2004

${ }^{8}$ Ibid.

${ }^{9}$ Byrne \& Raphael, 1997; Reynolds, 1999 dalam Ong, A.D, Bergemann, C.S, Bisconti, T.L, Wallace, K.A, $2004,5$. ${ }^{10}$ Ibid.

${ }^{11}$ Ong, A.D, Bergemann, C.S, Bisconti, T.L, Wallace, K.A, 2004. The Role of Daily, 6.

12 Bonanno G.A., Wortman C.B, Nesse R.M, 2004. Prospectine pattern of resilience and maladjustment during widowhood. Psychology and Aging. Vol. 19. no2. 260-271.
} 
lain secara relatif ${ }^{13}$. Ini berarti bahwa tidak semua wanita mengalami rasa kehilangan dengan kualitas yang sama.

Terdapat beragam faktor yang menyebabkan berbedanya kemampuan adaptasi para wanita terhadap kehilangan. Vacon, Lyall dan Rogers ${ }^{14}$ mengungkapkan adanya sumbangan dari faktor rendahnya sosioekonomi, serta sumbangan beberapa faktor demografi lainnya terhadap adaptasi masa kehilangan. Meskipun penelitian awal menunjukkan bahwa dukungan sosial dan kualitas hubungan dalam perkawinan berhubungan dengan proses penyesuaian ${ }^{15}$ namun beberapa ppenelitian terbaru mempertanyakan kesimpulan global tersebut. Misalnya penelitian yang dilakukan oleh Carr menunjukkan bahwa karakteristik-karakteristik perkawinan seperti kehangatan, konflik dan ketergantungan instrumental memiliki hubungan yang kompleks terhadap penyesuaian terhadap kehilangan pasangan. Hal yang sama diungkapkan oleh Morgan ${ }^{16}$ bahwa banyak dukungan yang diberikan kepada para janda (umumnya dari keluarga mereka) dipersepsi secara negatif oleh para wanita tersebut. Temuan-temuan ini sejalan dengan konsensus umum dalam berbagai literatur bahwa persepsi terhadap kualitas, kontinuitas dan ketersediaan dukungan lebih berhubungan erat terhadap tingkat kesejahteraan psikologis para wanita tersebut dibandingkan dengan bantuan instrumental konkrit yang diterima. ${ }^{17}$ Meskipun demikian, sebagai peneliti tetap berpendapat bahwa dukungan sosial merupakan salah satu faktor yang membentengi efek-efek negatif dari kehilangan pasangan. Teman, anggota keluarga, dan tetangga dapat memberikan berbagai dukungan emosional dan instrumental untuk membantu meringankan transisi dalam masa-masa sulit. ${ }^{18}$

Secara kontras, nampaknya faktor-faktor fenomenologis semacam ketiadaan rasa pesimisme dan persepsi terhadap kontrol merupakan faktor yang dapat memprediksi penyesuaian terhadap pasangan. ${ }^{19}$ Temuan ini menunjukkan adanya peran faktor kognitif yang mungkin memiliki hubungan langsung yang sedikit terhadap faktor-faktor yang lebih obyektif vis-avis

\footnotetext{
${ }^{13}$ Ibid.

${ }^{14}$ Miller \& Rahe, dalam Gallagher 1980 dalam O'Rourke, 2004

${ }^{15}$ Bonanno G.A., Wortman C.B, Nesse R.M, 2004. Prospectine pattern of resilience and. 271.

${ }^{16}$ Ibid

${ }^{17}$ Luthar.S, S \& Cicchetti, D. 2000

${ }^{18}$ Utz, R.L. 2005. The single older woman

${ }^{19}$ Ong, A.D, Bergemann, C.S, Bisconti, T.L, Wallace, K.A, 2004. The role of daily 7.
} 
penyesuaian terhadap masa janda setelah meninggalnya suami. ${ }^{20}$ Terkait dengan hal ini, teori mengenai resiliensi psikologis merupakan konsep yang lebih tepat dalam memahami penyesuaian pada masa kehilangan seperti yang akan dijelaskan di bawah.

Pemahaman terhadap rasa kehilangan yang terjadi karena perceraian memperoleh perhatian secara berbeda dalam penelitian. Dalam literatur yang memiliki perhatian terhadap perceraian menggambarkan secara jelas adanya perbedaan antara wanita yang mengalami perceraian dengan terlebih dahulu berinisiatif untuk melakukan perceraian dengan wanita yang tidak berinisiatif melakukan perceraian. Inisiator didefinisikan sebagai pasangan yang pertama kali mengajukan perceraian. ${ }^{21}$ Meskipun terdapat komponen subjektif yang kuat dalam persepsi terhadap status inisiator, mayoritas peneliti menyepakati bahwa mayoritas orang yang menjalani perceraian dapat mengidentifikasi apakah mereka atau pasangan mereka, atau mereka berdua yang berinisiatif untuk melakukan perceraian. ${ }^{22}$

Terdapat kesepakatan umum bahwa pengalaman perceraian lebih sulit bagi non inisiator dibandingkan inisiator. Penelitian menunjukkan bahwa non inisiator cenderung merasa sebagai korban dalam perubahan kehidupan yang tidak mereka inginkan atau yang mereka inginkan secara tidak pasti, ${ }^{23}$ bahwa mereka merasa memiliki yang kecil atau bahkan tidak memiliki kontrol terhadap perubahan ${ }^{24}$ dan bahwa mereka merasa ditolak. ${ }^{25}$ Hal ini juga menunjukkan bahwa non inisiator memiliki kesulitan yang lebih besar untuk menerima perceraian ${ }^{26}$ dan mengatasi rasa kehilangan dibandingkan ${ }^{27}$ dengan inisiator. Beberapa peneliti menyatakan bahwa non inisiator mungkin menemukan kesulitan khususnya untuk sepenuhnya mengakhiri hubungan mereka ${ }^{28}$ dan mendefinisikan ulang identitas mereka sebagai seorang yang dicerai. ${ }^{29}$ Sebaliknya inisiator, ditemukan dalam penelitian hampir memiliki kontrol penuh terhadap proses

\footnotetext{
${ }^{20}$ Miller \& Rahe, dalam Gallagher 1980 dalam O'Rourke, 2004

${ }^{21}$ Baum, Nehami. 2007. "Separation Guilt" in woman who initiate divorce. Clinical Sicial Work. 35: 55.

22 Ibid.

${ }^{23}$ Gray \& Silver, 1990 dalam Baum, Nehami. 2007. "Separation Guilt" in woman who initiate divorce. Clinical Sicial Work. 35: 55.

24 Ibid.

${ }^{25}$ Vannoy, 1995 dalam Baum, 2007

${ }^{26}$ Vaughan, 1986 dalam Baum, 2007

${ }^{27}$ Kincaid \& Cadwell, 1995 dalam Baum, 2007

${ }^{28}$ Spanier \& Casto, 1979; Weiss, 1975 dalam Baum, 2007

${ }^{29}$ Duran-Aydintug, 1`995; Vaughan, 1996 dalam Baum, 2007
} 
perceraian, ${ }^{30}$ memiliki keadaan yang lebih baik secara emosional dan psikologis dibandingkan dengan non inisiator ${ }^{31}$ dan seringkali, mengalami lebih banyak kelegaan pada saat perkawinan berakhir. $^{32}$

Perbedaan temuan-temuan ini tidak berarti bahwa perceraian bukan merupakan kesulitan emosional bagi inisiator. Perceraian merupakan sebuah kehilangan bagi inisiator sebagaimana pada non inisiator. Inisiator juga kehilangan pasangan mereka, kehilangan keluarga utuh mereka, rutinitas harian yang biasa mereka miliki, dan mereka juga harus berjuang untuk membangun sebuah kehidupan baru dan hubungan baru bagi diri mereka. Pada kenyatannya, Buehler dalam studinya terhadap sejumlah sampel yang mewakili para wanita yang mengalami perceraian ternyata menemukan bahwa inisiator benar-benar mengalami lebih banyak perubahan dan persoalan dibandingkan dengan non inisiator pada satu tahun setelah perceraian. ${ }^{33}$

Dalam beberapa penelitian mengenai para wanita yang mengalami perceraian, lebih dari separuh sampel merupakan inisiator perceraian. ${ }^{34}$ Dalam penelitian mengenai pembandingan proses yang dialami oleh inisiator dan non inisiator secara berulang menunjukkan bahwa non inisiator cenderung memiliki perasaan ditolak yang cukup kuat, sedangkan inisiator cenderung memiliki rasa bersalah. Menurut temuan-temuan penelitian, rasa bersalah seringkali terkait dengan kekhawatiran terhadap efek merusak yang dialami oleh anak-anak mereka setelah masa perceraian dan terkait dengan lepasnya citra mereka terhadap definisi-definisi yang diterima secara budaya mengenai orang tua yang baik, suami atau istri yang baik. ${ }^{35}$

Sejumlah peneliti telah menemukan pengaruh rasa bersalah terhadap penyesuaian perkawinan. Spanier \& Margolis $^{36}$ melihat bahwa individu yang mengalami perceraian berhubungan dengan penurunan kepuasan hidup setelah perceraian; ${ }^{37}$ menemukan adanya hubungan antara rasa bersalah ini dengan depresi. Beberapa penelitian juga menunjukkan bahwa

\footnotetext{
${ }^{30}$ Ibid.

${ }^{31}$ Buehler, 1987; Gray, 1996 dalam Baum, 2007

${ }^{32}$ Amato, 2000 dalam Baum, 2007

${ }^{33}$ Ibid.

${ }^{34}$ Buehler, 1987; ${ }^{34}$ Kincaid \& Cadwell, 1995 dalam Baum, 2007, 47.

${ }^{35} \mathrm{Ibid}$.

${ }^{36}$ Ibid.

${ }^{37}$ Walters-Chapman, Price dan Serovich (1995)
} 
perasaan bersalah menghalangi perpisahan psikologis dengan mantan pasangan. ${ }^{38}$ Weiss menemukan bahwa rasa bersalah mengganggu kemampuan ibu yang bercerai untuk mendefinisikan kembali identitas mereka di luar status perkawinan mereka. ${ }^{39}$ Pais dan White serta Raschke menemukan dalam penelitian mereka bahwa rasa bersalah memperburuk kesulitan-kesulitan yang dihadapi oleh individu yang bercerai dalam mendefinisikan kembali posisi dan peran mereka tidak hanya terhadap mantan pasangan tapi juga anak-anak mereka dan lingkungan sosial.

Berdasarkan uraian di atas terlihat bahwa kehilangan pasangan baik karena kematian atau karena perceraian memiliki resiko untuk terkena problem-problem psikologis sebagai bagian dari proses penyesuaian. Meskipun demikian, tidak semua wanita yang kehilangan seuami mengalami kondisi psikologis yang buruk dalam waktu lama. Dalam kajian psikologi, kondisi ini ditelaah dalam teori resiliensi sebagai kemampuan untuk menghadapi penyesuaian terhadap kondisi penuh tekanan secara relatif stabil tanpa mengalami gangguan yang berarti terhadap fungsi psikologisnya secara berkelanjutan.

\section{Resiliensi Psikologis}

Resiliensi psikologis sebagaimana yang didefinisikan oleh Maddi, Kobasa dan Kahn ${ }^{40}$ merefleksikan sebuah keyakinan bahwa individu dapat melakukan sebuah respon di bawah kondisi stress secara efektif. Kondisi ini mencakup tiga konstruk yang saling terkait. Pertama adalah komitmen terhadap hidup, yaitu adanya kecenderungan untuk melakukan aktivitas harian secara penuh termasuk melakukan hubungan dengan diri dan orang lain sehingga mereka menghargai nilai-nilai, tujuan-tujuan dan prioritas-prioritas hidup mereka yang berbeda dari oarang lain. Kedua adalah adanya pandangan individu bahwa perubahan adalah tantangan dan bahwa perubahan adalah hal yang normal. Ketiga, yaitu adanya keyakinan bahwa individu dapat mengontrol atau mempengaruhi kejadian-kejadian. Manifestasinya adalah adanya sebuah perasaan otonomi personan dan keyakinan bahwa individu dapat mempengaruhi nasib kehidupannya. $^{41}$

\footnotetext{
${ }^{38}$ Weiss 1975 dalam Baum, 2007

${ }^{39}$ Pais \& White 979 dalam Baum, 2007; Raschke 1987 dalam Baum, 2007

${ }^{40}$ Maddi, Kobasa dan Kahn 1982 dalam O'Rourke, 2004

41 Ibid.
} 
Dalamkonteks resilience to loss atau resiliensi terhadap kehilangan pada subjek dengan ciri khusus sebagai orang-orang yang mengalami kehilangan akibat kematian orang terdekat telah ditunjukkan dalam beberapa penelitian. ${ }^{42}$ Dalam penelitian-penelitian tersebut Bonanno dkk mendefinisikan resilien sebagai:

"the ability adults in otherwisw normal circumstances who are exposed to an isolated and potentially highly disruptive event such as the death of close relation or violent or life threatening situation to maintain relatively stable, healthy level of psychological and phisical functioning....as well as the capacity for generative experiences and positive emotion".

Rutter $^{43}$ mengungkapkan adanya empat fungsi resiliensi, yaitu: a) untuk mengurangi resiko mengalami konsekuensi-konsekuensi negatif setelah adanya kejadian-kejadian hidup yang menekan, b) mengurangi kemungkinan munculnya rantai reaksi yang negatif setelah peristiwa hidup yang menekan, c) membantu menjaga harga diri dan rasa mampu diri, dan d) meningkatkan kesempatan untuk berkembang. Resiliensi bukanlah karakteristik kepribadian atau trait tetapi lebih sebagai sebuah proses dinamis dengan disertainya sejumlah faktor yang membantu mengurangi resiko individu dalam menghadapi tekanan kehidupan. ${ }^{44}$ Hal serupa dinyatakan oleh O'Leary dan Ickoviks ${ }^{45}$ yang menyatakan meskipun seorang individu mungkin memperoleh keuntungan dan perubahan positif dari sebuah tantangan hidup, namun tidak ada jaminan bahwa hasil yang sama akan nampak ketika menghadapi tantangan-tantangan lain yang hampir bersamaan terjadi.

Dalam sebuah artikel yang mendiskusikan tentang kesehatan wanita, ${ }^{46}$ mengembangkan sebuah model resiliensi yang memandang resiliensi hanya sebagai sebuah homeostatis yang kembali pada ekuilibrium setelah adanya tantangan hidup. Ada empat tingkat yang berbeda yang dapat dihasilkan setelah mengalami tekanan hidup yaitu succumbing (mengalah, menyerah),

\footnotetext{
${ }^{42}$ Bonanno G.A., Wortman C.B, Lehman D.R., Twedd R.G., Haring M., Sonnega J., Carr D., Nesse R.M. 2002. Resilience to loss and chronic grief: a prospective study from preloss to 18 -months postloss. Journal of Personality and Social Psychology vo. 83, no.5, 1150-116

${ }^{43}$ Rutter 1987, dalam Coulson, 2006

${ }^{44}$ Luthar, 1991 dalam Coulson, 2006

${ }^{45}$ O'Leary dan Ickoviks, dalam Coulson, 2006

${ }^{46}$ Ibid.
} 
survival (bertahan), recovery (penyembuhan) dan thriving (berkembang). Empat tingkatan ini selanjutnya dikembangkan lebih jauh oleh Carver. ${ }^{47}$

Succumbing digambarkan sebagai sebuah papan yang melengkung ke bawah dimana individu biasanya menunjukkan sikap "menyerah" setelah menghadapi tekanan hidup. Tingkatan ini dapat terjadi ketika individu mendapati tantangan yang terlalu sulit atau terlalu besar. Akibatakibat potensial dari tantangan yang terlalu sulit ini adalah individu melarikan diri ke alkohol atau drug,mengalami depresi klinis, dan bahkan menginginkan bunuh diri. Survivor adalah tingkatan dimana individu tidak mampu meraih atau kembali pada tingkatan yang aman. Dalam fungsi-fungsi psikologis dan emosional mereka setelah dijumpainya kesulitan-kesulitan hidup. Individu dalam tingkatan ini mungkin mengalami perasaan-perasaan negatif, pikiran-pikiran atau prilaku-prilaku negatif, misalnya ketidakmampuan untuk membangun hubungan personal yang dekat, berkurangnya kepuasan kerja atau mungkin depresi.

Recoverer adalah individu yang mampu bangkit kembali pada tingkatan adaptasi dan fungsi psikologis-emosionalnya seperti semula sebelum dialaminya tekanan hidup tersebut meskipunada efek residual jangka panjang yang bersifat minimal. Recoverer terlibat kembali dengan beragam aktifitas dan menyatupadukan kembali kehidupan mereka; mereka inilah yang mewakili individu-individu yang disebut sebagai individu yang resilien. Thriver adalah individu yang bukan hanya kembali pada level awal fungsioning psikologis mereka sama seperti sebelum mengalami tekanan hidup, tetapi mereka benar-benar melampaui level ini dalam beberapa hal. O'Leary dan Ickoviks ${ }^{48}$ memandang level berkembang ini sebagai sebuah proses tranformatif yang memberikan nilai tambah kepada kehidupan. Nilai tambah ini mungkin ditampakkan secara prilaku, kognisi dan atau emosi dengan meningkatnya tujuan hidup, kejelasan visi, menyusun kembali prioritas peran sebagaimana makin menguatnya perkembangan keterampilanketerampilan baru termasuk dalam hubungan antarpersonal.

Secara lebih khusus memberikan gambaran adanya 5 pola inti kehilangan akibat kematian pasangan, pada 6 bulan dan 18 bulan pasca kematian, yaitu: a) common grief,

\footnotetext{
${ }^{47}$ Ong, A.D, Bergemann, C.S, Bisconti, T.L, Wallace, K.A, 2006. Psychological resilience, positive emotions, and successful adaptations to stress in later life. Journal of Personality and Social Psychology vol. 91, no.4, 730-749

${ }^{48}$ Ibid.
} 
merupakan reaksi umum pada bulan-bulan awal setelah kematian yang ditandai dengan munculnya tanda-tanda distres umum seperti depresi dan kecemasan, namun kemudian mengalami penurunan simtom kehilangan pada 6 bulan dan 18 bulan pasca kehilangan, b) chronic grief, yaitu reaksi terhadap kehilangan yang bersifat kronik, yang ketergantungan terhadap pasangan,yang ditunjukkan dengan masih tingginya simtom kehilangan 6 bulan dan 18 bulan pasca kematian, c) chronic depression, yaitu masih dijumpainya simtom ekhilangan yang tinggi disaat 6 bulan pasca kematian dan menurun sedikit saat 18 bulan pasca kematian, yang diakibatkan juga oleh adanya ketergantungan yang tinggi terhadap pasangan, d) depresedimproved yaitu adanya perbaikan tingkat depresi, pada 6 bulan dan 18 bulan pasca kematian dengan adanya simtom kehilangan yang rendah, yang disebabkan oleh rendahnya ketergantungan terhadap orang lain termasuk pasangan, dan e) resilien, yaitu individu yang menunjukkan rendahnya tingkat simtom kehilangan pada 6 bulan dan 18 bulan pasca kematian, yangh disebabkan oleh sikap penerimaan terhadap kematian secara umum sebelum benar-benar mengalami kehilangan dan pandangan terhadap dunia yang penuh dengan berbagai kemungkinan.

\section{Peran emosi positif}

Peran penting emosi positif dalam penyesuaian individu terhadapa stress dapat dijelaskan melalui the broaden-and-build theory of positive emotions yang disampaikan oleh Frederickson. Menurut teori ini, emosi positif dan negatif memiliki perbedaan dan nfungsi-fungsi adaptif yang saling melengkapi, termasuk juga efek-efek kognitif maupun psikologisnya. ${ }^{49}$ Emosi negatif mempersempit cadangan pikiran-tindakan sesaat dengan cara mempersiapkan individu untuk berprilaku dalam cara tertentu misalnya menyerang ketika marah atau lari ketika takut. Sebaliknya, beragam rentang emosi-emosi positif seperti kegembiraan, interes, kepuasan hati memperluas cadangan pikiran-tindakan serta melapangkan rentang kognisi dan prilaku yang menghampiri pikiran individu. Minset yang telah diperluas oleh emosi positif ini selanjutnya membangun sumber-sumber sosial, intelektual dan fisik pada individu. Dengan demikian teori ini lebih menempatkan emosi positif sebagai faktor yang mempercepat proses recovery yang

\footnotetext{
${ }^{49}$ Tugade, M.M, Frederickson, B.I. Barrett, L.F. 2004. Psychological resilience and positive emotional granularity: examining the benefits of positive emotions on coping and health. Journal of Personality 72:6, Desember
} 
adaptif. Penemuan terbaru yang lebih memperkuat pentingnya emosi positif dalam mempercepat recovery dari keadaan penuh stress ditunjukkan oleh hasil penelitian. ${ }^{50}$ Bkti kurangnya distresyang merupakan kondisi dominasi emosi negatif- selama masa kehilangan yang merupakan indikator relisiensi juga ditunjukkan oleh hasil-hasil penelitian ${ }^{51}$ yang meneliti pada anak-anak yang mengalami kehilangan di usia dini ${ }^{52}$ yang meneliti pada usia lanjut.

Peran penting emosi positif terhadap adaptasi stress juga dapat dijelaskan melalui dynamic model of affect (DMA) yang disampaikan oleh Zautra, dkk. ${ }^{53}$ Berbeda dengan model stress dan coping lain yang memandang adptasi emosional sebagai regulasi destress psikologis, DMA justru mempertimbangkan baik emosi positif maupun negatif dalam proses stress. Model ini memprediksikan bahwa dalam keadaan biasa, emosi positif dan negatif adalah independen. Namun, dalam keadaan penuh stress korelasi sebaliknya antara emosi positif dan negatif pada hari-hari ketika stress meningkat. Model ini juga memprediksikan bahwa berkurangnya pengalaman emosi positif akan meningkatkan kepekaan individu terhadap efek negatif sress.

Bukti empiris yang mendukung DMA diberikan oleh hasil-hasil penelitian yangh menunjukkan bahwa pengalaman emosi positif selama waktu-waktu penuh tantangan dapat menyumbangkan resistensi stress dan penyesuaian terhadap stress melalui terganggunya pengalaman emosi negatif yang sedang berlangsung selama waktu-waktu stress. ${ }^{54}$

Munculnya emosipositif merupaka hasil dari adanya regulasi emosi. Mengacu pada penjelasan Lazarus \& Alfert $^{55}$ bahwa regulasi emosi memiliki dua bentuk strategi, yaitu Cognitive reappraisal dan expressive suppression. Cognitive reappraisal merupakan bentuk perubahan kognitif yang melibatkan penafsiran terhadap situasi yang secara potensial memunculkan emosi,melalui suatu cara yang mampu merubah pengaruh emosionalnya. Bentuk

\footnotetext{
${ }^{50}$ Frederickson, dkk 2003, Tugade \& Frederickson, 2004 dan Zutra, Johnson \&Davis 2005.

${ }^{51}$ Luthar S, S \& Cicchetti, D. 2000 the constructof resilience: implications for interventions and social policies. Developmental and psychopatology, 12, 857-885

${ }^{52}$ Ong, A.D, Bergemann, C.S, Bisconti, T.L, Wallace, K.A, 2006. Psychological resilience, positive emotions, and successful adaptations to stress in later life. Journal of Personality and Social Psychology vol. 91, no.4, 730-749

${ }^{53}$ Ibid.

${ }^{54}$ Ibid.

${ }^{55}$ Gross, J.J \& John, O.P. 2003. Individual Differences in two emotion regulation processes: implications for affect, relationships and well-being. Journal of Personality and Social Psychology vol. 85, no.2, 348-362
} 
ini merupakan antecedent focused strategy yang terjadi pada saat awal sebelum kecenderungan respon emosi terbangkitkan secara penuh. Hal ini berarti bahwa cognitive reappraisal dapat merubah seluruh lintasan emosi berikutnya secara efisien. Lebih khusus lagi, ketika digunakan untuk meregulasi penurunan emosi negatif baik secara prilaku maupun secara experimental.

Expressive suppression merupakan sebuah bentuk modulasi respon yang melibatkan penghentian prilaku ekspresi emosi. Suppression merupakan a respon-focused strategy yang datangnya relatif lambat dalam proses pembangkitan emosi dan memodifikasi aspek prilaku dati kecenderungan respon emosi. Suppression mungkin efektif dalam mengurangi ekspresi emosi negatif secara prilaku namun mungkin juga memiliki efek samping yang tidak diharapkan yaitu mengawasi ekspresi emosi positif secara ketat. Pada saat yang sama, suppression tidak akan membantu mengurangi pengalaman emosi negatif karena tidak menjadi target dari suppression sehingga akan terus melekat dan terakumulasi tanpa penyelesaian. Penelitian yang dilakukan oleh Gross dan John ${ }^{56}$ menunjukkan bahwa individu yang menggunakan strategi reappraisal memiliki pengalaman emosi positif yang lebih besar serta ekspresi emosi positif yang lebih besar pula. Sedangkan individu yang menggunakan strategi suppression lebih sering menunjukkan ekspresi emosi negatif sekaligus lebih sering mengalami emosi positif.

Sekalipun emosi positif tidak diragukan menjadi akibat dari coping (cara pengatasan masalah) individu dan resilien, ${ }^{57}$ namun bukti lain menunjukkak bahwa individu yang resilien mungkin juga menggunakan emosi-emosi positif untuk memperoleh efektifitascoping. Sejumlah strategi coping memiliki kemampuan untuk mengolah satu jenis emosi positif atau lebih seperti rasa senang, interes, kepuasan atau harapan. Adalah hal yang mengesanan bahwa individu yang resilien tidak hanya mengolah emosi positif untuk coping tapi mereka juga terlatih untuk memperoleh emosi positif saat mendekati orang lain, yang selanjutnya bisa menciptakan sebuah konteks dukungan sosial yang dapat memfasilitasi coping. ${ }^{58}$ Beberapa penelitian menunjukkan bnahwa individu-individu yang resilien memiliki optimisme, semangat dan pendekatan yang

\footnotetext{
${ }^{56}$ Ibid.

${ }^{57}$ Block J. \& Kremen. 1996. IQ and ego-resiliency: conceptual and empirical connections and separates. Journal of Personality and Social Psychology vol. 70, no.2, 349-361

${ }^{58}$ Fredrickson. B.L. Tugade. M.M. Waugh. C.C. Larkin G.R. 2003. what good are positive emotions in crises? A prospective study of resilience and emotions following the terrorist attacts on the United States on September $11^{\text {th }}$, 2001. Journal of Personality and Social Psychology vol. 84., no.2,365-376
} 
energik terhadap kehidupan, bersikap terbuka terhadap pengalaman-pengalaman baru dan memiliki emosi positif yang tinggi. ${ }^{59}$

Emosi positif dengan demikian memiliki manfaat yang sangat penting, khususnya ketika emosi positif ini hadir dalam waktu-waktu sterss. Strategi untuk mengembangkan emosi positif antara lain dengan humor pada saat-saat penuh teknan sebagai salah satu bentuk coping. ${ }^{60}$

Hal lain yang dapat mempengaruhi munculnya emosi positif adalah religi. Dalam hal memahami mekanisme bagaimana religi dapat berpengaruh terhadap kesejahteraan psikologis, Pollner (1989) menyampaikan tiga hipotesis mengenai hal tersebut, yaitu, a) religi dapat memberikan sebuah sumber untuk menjelaskan dan menyelesaikan situasi-situasi bermasalah, b) religi dapat berperan meningkatkan perasaan positif sebagai sesuatu yang memberikan kekuatan, c) religi memberikan dasar untuk munculnya rasa bermakan, pemberian petunjuk dan identitas personal. Dengan demikian, religi mungkin tidak menyumbangkan hubungan secara langsung dengan kesejahteraan psikologis namun dengan memberikan makna dan petunjuk dalam kehidupan.

Hal yang serupa diungkapkan oleh Baumister (1991) bahwa fungsi psikologis yang utama dari makan hidup adalah kemampuan agama dalam membantu keadaan internal seperti prilaku dan emosi manusia. Berkaitan dengan religi sebagai szumber pemberi makna hidup yang memiliki hubungan dengan emosi manusia, James ${ }^{61}$ menyatakan bahwa elemen mendasar dari religi adalah perasaan. James kemudian menyimpulkan bahwa 4 karakteristik pengalaman emosi yang berhubungan dengan religi yaitu: a) perasaan damai, b) perasaan untuk memiliki insight ketika menghadapi permasalahan, c) persaan kebaruan yang memperindah setiap objek, dan d) kebahagiaan. Dengan kata lain, James memandang bahwa religi menyumbangkan hal penting dalam memunculkan perasaan-persaan khususnya emosi positif.

\footnotetext{
${ }^{59}$ Ibid.

${ }^{60}$ Hobfol, 1989; Kuiper, Martin \& Dance, 1992; Folkman \& Moskowitz, 2000 dalam Ong, A.D, Bergemann, C.S, Bisconti, 2004. The role of daily positive emotions during conjugal bereavement. The Journal of Gerontology, July, 59B, 4.

${ }^{61}$ Peter Hill C., 2001. Spritual Transformation: forming the habitual center of personal energy. Psychology of Religion. Newsletter. American Psychological Association, Volume 26, No.4
} 
Dalam koteks kehilangan pasangan, masa kesendirian setelah kehilangan pasangan merupakan sebuah kesempatan untuk menemukan diri yang terkubur oleh begitu banyak selubung identitas sebagai anak, istri dan ibu. Masa janda merupakan masa yang dapat dipersembahkan untuk mengembangkan kebutuhan-kebutuhan personal seperti penemuan diri, pembaruan diri dan refleksi. ${ }^{62}$ Wanita pada masa janda ini dapat mengalami pertumbuhan personal karena ia mengetahui bahwa ia tak harus bergantung pada orang lain untuk bertahannya diri dalam melewati kehidupan sehari-hari. Dengan adanya emosi positif yang dihadirkan melalui humor sebagai bentuk pengatasan masalah dan agama sebagai sesuatu yang memberikan sumber makna terbesar dalam memaknai semua pengalaman hidup termasuk pengalamanpengalaman yang menyakitkan, maka resiliensi pada wanita yang mengalami kehilangan pasangan akan dapat diwujudkan.

\section{E. Kesimpulan}

Rasa kehilangan, akibat perpisahan baik karena kematian atau perceraian adalah suatu respon yang wajar terhadap tekanan hidup. Sekalipun demikian, respon individu dalam hal intensitas dan lamanya melakukan penyesuaian terhadap rasa kehilangan dapat bervariasi pada tiap individu. Sebagian mengalami simtom kehilangan berupa kecemasan dan depresi dalamj jangka yang panjang, namun sebgaian wanita memiliki penyesuaian yang cepat terhadap rasa kehilangan. Wanita yang memiliki resiliensi cenderung mampu melakukan proses penyesuaian yang cepat terhadap rasa kehilangan. Salah satu faktor yang turut membantu proses pemulihan rasa kehilangan pada wanita yang memiliki resiliensi adalah emosi positif, yang digunakan baik sebagai sebuah bentuk coping atau model pengatasan masalah maupun digunakannya emosi positif untuk mencapai efektifitas coping dengan bentuk yang lain. Dengan demikian individu yang cenderung mengalami lebih banyak emosi positif akan menjadi lebih tahan terhadap kondisi-kondisi penuh tekanan termasuk kehilangan pasangan baik karena kematian maupun perceraian.

\footnotetext{
${ }^{62}$ Utz, R.L. 2005. The Single older woman: Life after marriage. Book Reviews. The Gerontologist: June, 45, 3
} 


\section{DAFTAR PUSTAKA}

Baum,Nehami. 2007. "Separation Guilt" in woman who initiate divorce. Clinical Sicial Work. 35: 55 .

Baumister, R.F. 1991. Meaning of Life.New York: Guilford Press

Block J. \& Kremen. 1996. IQ and ego-resiliency: conceptual and empirical connections and separates. Journal of Personality and Social Psychology vol. 70, no.2, 349-361

Bonanno G.A., Wortman C.B, Lehman D.R., Twedd R.G., Haring M., Sonnega J., Carr D., Nesse R.M. 2002. Resilience to loss and chronic grief: a prospective study from preloss to 18-months postloss. Journal of Personality and Social Psychology vo. 83, no.5, 1150116

Bonanno G.A., Wortman C.B, Nesse R.M, 2004. Prospectine pattern of resilience and maladjustment during widowhood. Psychology and Aging. Vol. 19. no2. 260-271

Bonanno G.A.. 2005. Clarifying and extending the constract of adult resilience. American psychologist. Vol. 60. 265-267

Fredrickson. B.L. Tugade. M.M. Waugh. C.C. Larkin G.R. 2003. what good are positive emotions in crises? A prospective study of resilience and emotions following the terrorist attacts on the United States on September $11^{\text {th }}$, 2001. Journal of Personality and Social Psychology vol. 84., no.2,365-376

Gross, J.J \& John, O.P. 2003. Individual Differences in two emotion regulation processes: implications for affect, relationships and well-being. Journal of Personality and Social Psychology vol. 85, no.2, 348-362

Hill, Peter C., 2001. Spritual Transformation: forming the habitual center of personal energy. Psychology of Religion. Newsletter. American Psychological Association, Volume 26, No.4

Klohnen, E.C. 1996. Conceptual Analysis and Measurement of the Construct of Ego-Resiliency. Journalof personality and social psychology Vol. 70 No.5 1067-1079

Luthar S, S \& Cicchetti, D. 2000 the constructof resilience: implications for interventions and social policies. Developmental and psychopatology, 12, 857-885

Ong, A.D, Bergemann, C.S, Bisconti, 2004. The role of daily positive emotions during conjugal bereavement. The Journal of Gerontology, July, 59 B, 4.

Ong, A.D, Bergemann, C.S, Bisconti, T.L, Wallace, K.A, 2006. Psychological resilience, positive emotions, and successful adaptations to stress in later life. Journal of Personality and Social Psychology vol. 91, no.4, 730-749 
Tugade, M.M, Frederickson, B.I.. 2004. Resilience Individuals use positive emotions to bounce back from negative emotional experiences. Journal of Personality and Social Psychology Vol. 86, No. 2, 320-333.

Tugade, M.M, Frederickson, B.I. Barrett, L.F. 2004. Psychological resilience and positive emotional granularity: examining the benefits of positive emotions on coping and health. Journal of Personality 72:6, Desember

Tusaie, K \& Dyer, J. 2004. Resilience: a historical review of the construct. Holistic Nursing Practice. January/February, 1-7

Utz, R.L. 2005. The single older woman: life after marriage. Book Reviews. The Gerontologist: June, 45, 3.

Zautra, A.J, Johnson, L.M, \& Davis, M.C. 2005. Positive affects as asource of resilience for women in chronic pain. Journal of Personality and Social Psychology vol. 86, no.2, 320333

Zautra, A.J, Smith. B. Affleck G, Tennen H. 2001. Examination of chronic pain and affect relationship: applications of adynamic model of affect. Journal of Consulting and Clinical Psychology, 69, 786 